\title{
PERSICARIA NEPALENSIS (POLYGONACEAE), A NEW POTENTIALLY INVASIVE ANTHROPOPHYTE IN THE POLISH FLORA
}

\author{
Tomasz KowalczyK ${ }^{1}$, Artur Pliszko \& Szymon M. Drobniak
}

\begin{abstract}
Persicaria nepalensis (L.) Mill. is an annual herb occurring natively in South, East and Southeast Asia, having a range extending from Oceania to East Africa. Here we report the first Polish stand of this species, found in 2011 near Baligród (Western Bieszczady Mountains), followed by the discovery of two more stands in the surrounding area up to 2013. The floristic composition of vegetation impacted by $P$. nepalensis is presented, and the invasive potential and pathways of introduction of the species are briefly discussed.
\end{abstract}

Key words: alien species, Bieszczady Mts, Carpathians, distribution, Persicaria nepalensis, Poland

Tomasz Kowalczyk \& Artur Pliszko, Institute of Botany, Jagiellonian University, M. Kopernika 27, Kraków 31-501, Poland; e-mail: tomasz.kowalczyk@uj.edu.pl

Szymon M. Drobniak, Institute of Environmental Science, Jagiellonian University, Gronostajowa 7, Kraków 30-387, Poland, and Anthropological Institute and Museum, University of Zurich, Winterthurerstrasse 190, CH-8057 Zürich, Switzerland

\section{INTRODUCTION}

Persicaria (L.) Mill. (Polygonaceae) is one of the species-richest genera in the alien flora of Europe, especially in the southern part of the continent (Lambdon et al. 2008). Some of its species are distant intercontinental introductions, such as $P$. pensylvanica (L.) M. Gómez transferred from North America (Kubát \& Jehlík 2003) and P. capitata (Buch.-Ham. ex D. Don) H. Gross originating from South Asia (Nogueira et al. 2006).

In Poland the genus Persicaria is represented by three anthropophytes. Two of them are considered ephemerophytes [P. bungeana (Turcz.) Nakai, P. orientalis (L.) Spach.]. Persicaria walichii Greuter \& Burdet is classified as an invasive kenophyte (Mirek et al. 2002; Bartoszek et al. 2006; Tokarska-Guzik et al. 2012).

During a floristic study in the Western Bieszczady Mountains in 2011 a population of Persicaria nepalensis (Meisn.) H. Gross, a species new both to the Polish flora and to the flora of the Carpathians, was discovered.

\footnotetext{
1 Corresponding author
}

\section{Materials AND METHODS}

Persicaria nepalensis was discovered during floristic surveys done in 2011-2013 in the Pogórze Leskie foothills and in the northern part of the Western Bieszczady Mts (Eastern Carpathians). The researched area is bounded by the San River to the north, the Osława River to the west, the road between Rzepedź and Wołkowyja to the south, and the western shores of the Solina Reservoir to the east (Fig. 1). In each of the three P. nepalensis stands discovered we made a relevé following the BraunBlanquet method as modified by Dzwonko (2007). The floristic relevés of the $P$. nepalensis habitats studied are given in Table 1. Persicaria nepalensis specimens were collected from each discovered location. Specimens are deposited in the Herbarium of the Institute of Botany of the Jagiellonian University in Kraków (KRA).

\section{RESULTS}

Persicaria nepalensis (Meisn.) H. Gross

Bot. Jahrb. Syst. 49: 277. 1913. - Polygonum nepalense Meisn., Monogr. Gen. Polyg.: 84. 1826.

Erect, ascending or decumbent annual, $15-50 \mathrm{~cm}$ high. Stem usually branched, rooting at lower 


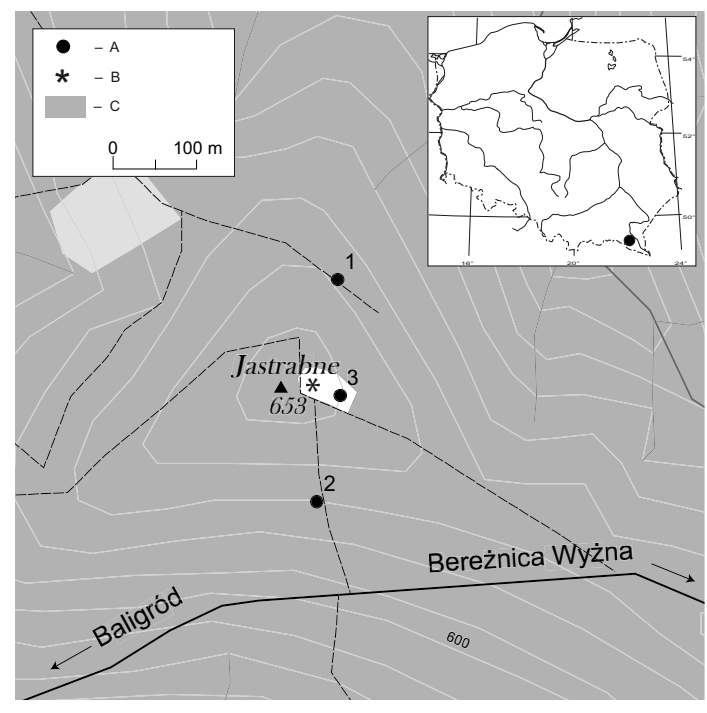

Fig. 1. Stands of Persicaria nepalensis (Meisn.) H. Gross in Poland. A - stands of P. nepalensis, B -raised blind, C - forests.

nodes, round, glabrous except for whitish glandular trichomes on upper parts of internodes. Leaves alternate, $1.4-5.0 \times 1.0-3.0 \mathrm{~cm}$; heterophyllous: lower leaves broadly ovate or rhomboid with truncate base, petiolate, petiole $2-3 \mathrm{~cm}$ long, slightly to moderately winged; upper leaves oblanceolate, subsessile or subamplexicaul with auricled base. Lamina with entire and slightly scabrous margin, revolute, undulate, glabrous on adaxial surface, pubescent on veins and punctate with yellow glands on abaxial surface, apex acute (Fig. 2a-c). Ochreae tubular, truncate, 5-10 mm long, strigose proximally, brownish. Inflorescences terminal and axillary corymbose heads, 6-7 $\mathrm{mm}$ in diameter, subtended by sessile, subamplexicaul, ovate to lanceolate leaves $(6.5-12.5 \times 2.5-5.0 \mathrm{~mm})$, peduncles 1-20 mm long, erect with glandular hairs below heads. Ochreolae ovate-lanceolate, acute, $3-5 \times 2 \mathrm{~mm}$. Flowers $2.5-4.0 \times 1.0-2.0 \mathrm{~mm}$, shortly pedicellate. Tepals $4(-5), 2.9-3.5 \times 0.6-$ $1.5 \mathrm{~mm}$, obtuse, obovate, usually pink, sometimes white or lavender. Stamens 5(-8), filaments 0.5$1.5 \mathrm{~mm}$ long, anthers black-purple, elliptic, ovary biconvex or trigonous with 2(-3) unequal styles, stigmas capitate. Fruit (nut) biconvex or trigonous, 1.0-2.0 × 1.0-1.9 mm, dull, shining, densely and minutely pitted, light or dark brown to black, enclosed in perianth (Fig. 2d). Flowering in JuneSeptember.

Description follows Qaiser (2001), Li et al. (2003), Hinds and Freeman (2005) and Yasmin (2009), modified following our own observations.

Persicaria nepalensis is sometimes confused with the closely related P. runcinata (Buch.-Ham. ex D. Don) H. Gross and P. capitata (Buch.-Ham. ex D. Don) H. Gross of the same section Cephalophilon, mainly due to their capitate inflorescences and truncate ochreas (Kim \& Donoghue 2008; Galasso et al. 2009).

\section{GENERAL DISTRIBUTION AND ECOLOGY}

Persicaria nepalensis is a paleotropical species. Its native geographical range span tropical and subtropical mountain regions of South, East and Southeast Asia, reaching Oceania and East Africa. In Asia it has been reported from India, Pakistan, Afghanistan, Nepal, Bhutan, Ceylon, Thailand, the Philippines, Malaysia, Indonesia, China, Japan, South Korea and Russia (Qaiser 2001; Li et al. 2003; Nogueira et al. 2006). It was also found in PapuaNew Guinea (Oceania) (Li et al. 2003), Kenya, Ethiopia, Tanzania, Uganda, Zambia and Malawi (Africa) (Nogueira et al. 2006). Outside its native range, $P$. nepalensis is occasionally introduced accidentally to other regions. In favorable conditions it readily colonizes, sometimes exhibiting expansive or even invasive tendencies. Persicaria nepalensis was introduced accidentally to the Asian part of Turkey (Tan \& Baytop 1995) and also to Europe and both Americas. In Europe it is an established anthropophyte in Italy (Pignatti-Wikus 1973, Webb et al. 1993), Great Britain (Stace 2010), Germany (Diekjobst 1994; Brandes 1995; Aboling 2008) and most likely also Belgium (Verloove 2013). It has been reported from the USA and Canada (Hinds \& Freeman 2005) and Mexico (Vibrans \& HananAlipi 2008). In South America it has been found in Ecuador (Jørgensen \& León-Yánez 1999), Columbia and Venezuela (Meier 2006).

Persicaria nepalensis prefers mountain slopes and river valleys, and is usually found in humid, partially shaded locations, mainly along muddy, gravelly and stony banks of mountain streams and 

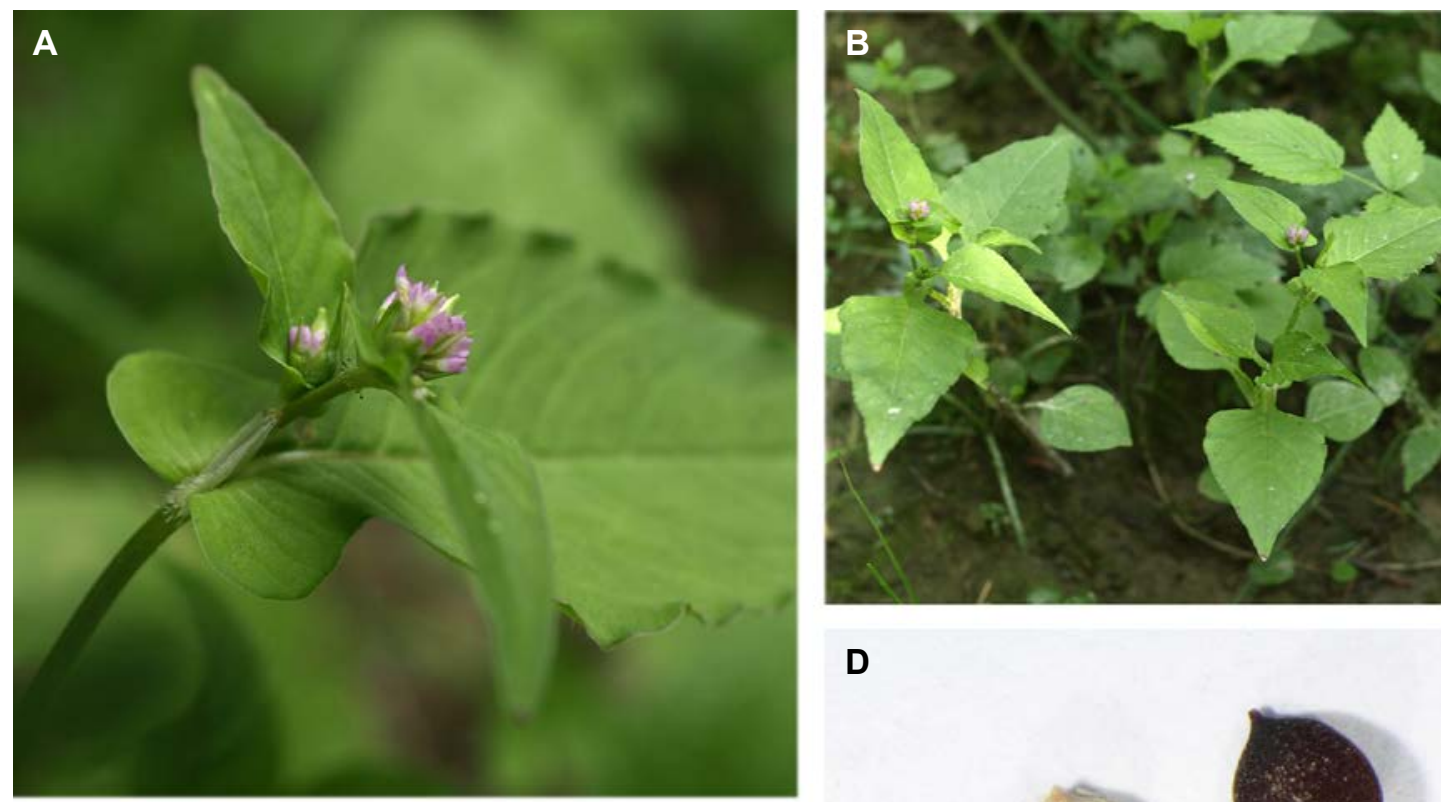

D
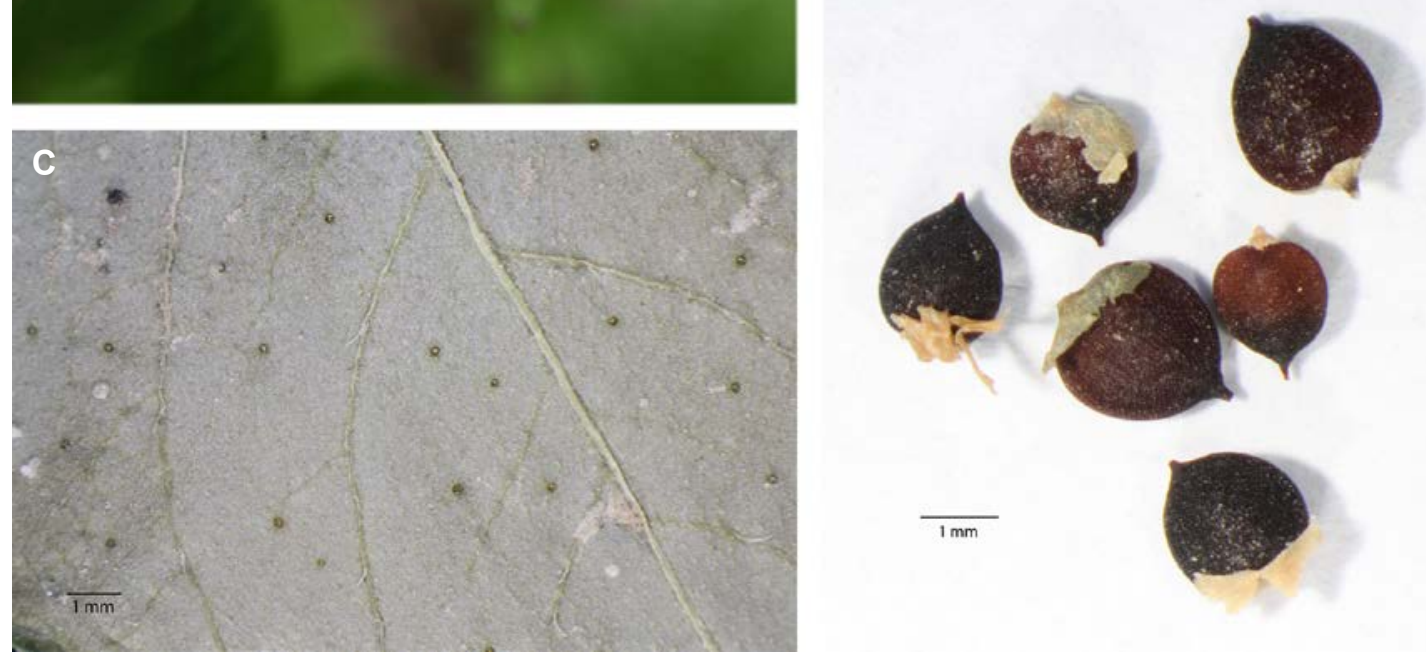

Fig. 2. Persicaria nepalensis (Meisn.) H. Gross. A \& B - plant's habit in the field, C - abaxial surface of leaf lamina with glands, D - fruits.

along forest edges. Depending on the geographic location its altitude tolerance ranges from 200 to 4000 m a.s.l. (e.g., Qaiser 2001; Li et al. 2003). Since $P$. nepalensis is an annual herb exhibiting rapid growth, a high reproductive rate and high fertility, it is relatively resistant to disturbances in its environment. Within its natural range it often becomes an apophyte, spreading to various humantransformed habitats such as forest felling areas, fields, gardens, banks of artificial canals, roadsides and landfills.

\section{OCCURRENCE IN POLAND}

The first stand of $P$. nepalensis was found in August 2011, $2 \mathrm{~km}$ east of Baligród in the Western Bieszczady Mountains. In July 2013 the first stand was confirmed and two more were found. All three stands are located within a few hundred meters of each other (Fig. 1). Persicaria nepalensis grew on rarely used, partly overgrown forest paths. The canopy of the first stand (no. 1 in Fig. 1) is dominated by Picea abies, Fraxinus excelsior, Acer 
Table 1. Floristic relevés of the studied Persicaria nepalensis (Meisn.) H. Gross. habitats.

\begin{tabular}{|c|c|c|c|}
\hline No. of relevé & 1 & 2 & 3 \\
\hline Location & Baligród & Baligród & Baligród \\
\hline Latitude $[\mathrm{N}]$ & $49^{\circ} 20^{\prime} 21,1^{\prime \prime}$ & $49^{\circ} 20^{\prime} 12,2^{\prime \prime}$ & $49^{\circ} 20^{\prime} 15,7^{\prime \prime}$ \\
\hline Longitude [E] & $22^{\circ} 19^{\prime} 12,1^{\prime \prime}$ & $22^{\circ} 19^{\prime} 10,1^{\prime \prime}$ & $22^{\circ} 19^{\prime} 09,9^{\prime \prime}$ \\
\hline Date & 9.07 .2013 & 9.07 .2013 & 27.07 .2013 \\
\hline Area of relevé $\left[\mathrm{m}^{2}\right]$ & 5 & 14 & 25 \\
\hline Plant cover [\%] & 50 & 40 & 95 \\
\hline Slope $\left[{ }^{\circ}\right]$ & 10 & 30 & 5 \\
\hline Exposition & NE & $\mathrm{S}$ & $\mathrm{E}$ \\
\hline No. of species & 27 & 33 & 27 \\
\hline Persicaria nepalensis & + & 1 & 4 \\
\hline Achillea millefolium $\mathrm{L}$. & . & + & + \\
\hline Agrimonia eupatoria $\mathrm{L}$. & . & + & . \\
\hline Agrostis capillaris L. & . & . & + \\
\hline Agrostis stolonifera $\mathrm{L}$. & + & . & . \\
\hline Anthemis arvensis $\mathrm{L}$. & . & + & 1 \\
\hline Athyrium filix-femina (L.) Roth & + & . & . \\
\hline Bidens frondosa $\mathrm{L}$. & . & . & + \\
\hline Callitriche cophocarpa Sendtn. & + & . & . \\
\hline Carex remota $\mathrm{L}$. & + & . & . \\
\hline Carex sylvatica Huds. & + & + & . \\
\hline Centaurea cyanus $\mathrm{L}$. & . & . & + \\
\hline Centaurea jacea $\mathrm{L}$. & . & + & . \\
\hline Cerastium sp. & + & . & . \\
\hline Cirsium arvense (L.) Scop. & . & + & 1 \\
\hline Echinochloa crus-galli (L.) P. Beauv. & . & . & + \\
\hline Elymus repens (L.) Gould. & . & + & 2 \\
\hline Euphorbia serrulata Thuill. & . & + & . \\
\hline Galeopsis tetrahit $\mathrm{L}$. & . & . & + \\
\hline Galinsoga ciliate (Raf.) S. F. Blake & . & . & 1 \\
\hline Geranium sp. & . & + & . \\
\hline Glechoma hederacea $\mathrm{L}$. & + & . & . \\
\hline Glyceria notata Chevall. & + & + & . \\
\hline Hepatica nobilis Schreb. & $\mathrm{r}$ & . & . \\
\hline Holcus mollis $\mathrm{L}$. & . & . & + \\
\hline Hypericum humifusum $\mathrm{L}$. & . & + & . \\
\hline Hypericum maculatum Crantz & . & + & + \\
\hline Impatiens parviflora $\mathrm{DC}$. & 2 & + & . \\
\hline Juncus effuses L. & + & + & . \\
\hline Juncus tenuis Willd. & . & + & . \\
\hline Lapsana communis L. & . & + & . \\
\hline Medicago lupulina $\mathrm{L}$. & . & + & . \\
\hline Mentha arvensis $\mathrm{L}$. & . & + & 1 \\
\hline Millium effusum $\mathrm{L}$. & + & . & . \\
\hline Myosotis sylvatica Ehrh. ex Hoffm. & + & . & . \\
\hline Oxalis acetosella $\mathrm{L}$. & + & . & . \\
\hline Polygonum hydropiper L. & 1 & + & . \\
\hline Polygonum lapathifolium $\mathrm{L}$. & . & . & + \\
\hline Phleum pretense L. & . & + & . \\
\hline
\end{tabular}


Table 1. Continued.

\begin{tabular}{|c|c|c|c|}
\hline No. of relevé & 1 & 2 & 3 \\
\hline Plantago major L. & + & 1 & . \\
\hline Poa annua $\mathrm{L}$. & . & + & . \\
\hline Poa palustris L. & . & + & . \\
\hline Prunella vulgaris Huds. & + & 1 & . \\
\hline Ranunculus repens $\mathrm{L}$. & 1 & + & . \\
\hline Raphanus raphanistrum $\mathrm{L}$. & . & . & + \\
\hline Rumex obtusifolius L. & 2 & 1 & . \\
\hline Senecio nemorensis agg. & + & . & . \\
\hline Spergula arvensis L. & . & . & 2 \\
\hline Stachys palustris L. & . & . & 2 \\
\hline Stachys sylvatica L. & + & . & . \\
\hline Stellaria graminea L. & . & + & . \\
\hline Trifolium aureum Pollich & . & + & . \\
\hline Trifolium pretense L. & . & + & . \\
\hline Trifolium repens $\mathrm{L}$. & . & + & . \\
\hline Tussilago farfara $\mathrm{L}$. & + & + & . \\
\hline Veronica filiformis $\mathrm{Sm}$. & . & + & . \\
\hline \multicolumn{4}{|l|}{ CULTIVATED PLANTS } \\
\hline Avena sativa $\mathrm{L}$. & . & . & 1 \\
\hline Brassica napus L. & . & . & + \\
\hline Helianthus tuberosus L. & . & . & + \\
\hline Pisum sativum L. & . & . & + \\
\hline Solanum tuberosum L. & . & . & + \\
\hline Triticum aestivum L. & . & . & + \\
\hline Vicia faba $\mathrm{L}$. & . & . & + \\
\hline Vicia sativa $\mathrm{L}$. & . & . & + \\
\hline Zea mays $\mathrm{L}$. & . & . & + \\
\hline
\end{tabular}

pseudoplatanus, Abies alba and Fagus sylvatica; the second stand (no. 2) is dominated by Larix decidua, Picea abies and Sambucus nigra. The third stand (no. 3) is a small field where vegetables are cultivated to be used as bait for game, near a raised blind. Persicaria nepalensis is clearly spreading from this location, following along a forest road. The first two stands comprise $c a 15$ individual plants; in the third one we noted $c a 20,000$ plants.

1. Baligród - rarely used forest path, $49^{\circ} 20^{\prime} 21.1^{\prime \prime} \mathrm{N} / 22^{\circ} 19^{\prime} 12.1^{\prime \prime} \mathrm{E}$, alt. $641 \mathrm{~m}, 14 \mathrm{Aug}$. 2011, leg. T. Kowalczyk.

2. Baligród - rarely used forest path, $49^{\circ} 20^{\prime} 12.2^{\prime \prime} \mathrm{N} / 22^{\circ} 19^{\prime} 10.1^{\prime \prime} \mathrm{E}$, alt. $626 \mathrm{~m}, 9$ July 2013, leg. Sz. Drobniak \& T. Kowalczyk.

3. Baligród - small field at a raised blind, $49^{\circ} 20^{\prime} 15.7^{\prime \prime} \mathrm{N} / 22^{\circ} 19^{\prime} 09.9^{\prime \prime} \mathrm{E}$, alt. 647 m, 27 July 2013, leg. T. Kowalczyk \& A. Pliszko.
Table 1 presents the relevés taken from the recorded $P$. nepalensis stands.

\section{DisCUSSION}

Persicaria nepalensis occurs in Poland in humantransformed habitats. From the distribution of the discovered stands and the numbers of individual plants in the respective locations we can infer both the probable origin of these plants and the potential pathways of further expansion of the species. Since the density of the plants was highest at the third location $(75 \%$ of the projective coverage in the relevé), the raised blind and the small field directly adjacent to it are the most likely points of origin, from where the plant began to expand its range along the road at the east side of the field. Persicaria nepalensis seeds probably were 
accidentally transferred to the field with sowing material used to grow cultivated species. The other two stands along forest paths have much lower densities of $P$. nepalensis, which suggests their secondary origin. Although impurities in sowing material are the most likely source of seeds of this species, other explanations cannot be ruled out at this stage. The $P$. nepalensis seeds may have been brought to the studied area accidentally by tourists. Finally, the P. nepalensis seeds may have been transferred with seeds of other plants used as bird food - this mode of transport had already been suggested in the case of the German populations of this species (Diekjobst 1994; Aboling 2008). The much higher density of $P$. nepalensis at the third stand may also be attributable to more favorable conditions at that site.

Irrespective of the origin of $P$. nepalensis in our flora, the discovery of this species offers a rare opportunity to observe the expansion of a potentially invasive species in Poland. Persicaria nepalensis most likely arrived in the studied area recently and spread quickly from its original location. Its wide range of ecological tolerance suggests that it may quickly spread to new habitats. In other countries the expansion of $P$. nepalensis (especially into human-transformed habitats) has already caused serious problems. In both Americas it has been classified as an invasive species (Meier 2006; Vibrans \& Hanan-Alipi 2008). In Asia it significantly affects the tea crop and in Africa it is one of the most common and most aggressive weeds, substantially decreasing the yields of wheat, coffee and other cultivated plants (Gebre et al. 1988; Nimje 1988; Njoroge 1994; Kefyalew et al. 2000; Roder et al. 2009; Asres \& Das 2011; Li et al. 2012).

In the near future the further expansion of $P$. nepalensis in the studied area along roads and forest paths should be expected. Given the potential threats to the economy and nature associated with the expansion of this species, we suggest that the $P$. nepalensis population requires monitoring as well as measures to contain its expansion. Possible steps include controlling the seed material used by hunters, and mowing existing stands of P. nepalensis, preferably before flowering.
ACKNOWLEDGEMENTS. We are grateful to the anonymous reviewers for helpful remarks and suggestions on the manuscript. This project was financed by the National Science Center (no. DEC-2012/07/N/NZ8/00117).

\section{REFERENCES}

Aboling S. 2008. Persicaria nepalensis (Meisn.) H. Gross Erstnachweis für Niedersachsen. Floristische Rundbriefe 41: 33-38.

AsRes B. \& DAS T. K. 2011. Diversity and integrated management of weeds in highland wheat of Northern Ethiopia. Plant Protection Quarterly 26(1): 8-16.

Bartoszek W., Urbisz A. \& ToKarsKa-GuZIK B. 2006. Polygonum polystachyum Wall. ex Meissner in Poland: status, distribution, habitats. Biodivers. Res. Conservation 1-2: 86-88.

Brandes D. 1995. Die Uferflora im Bereich des Lago Maggiore. Floristische Rundbriefe 29(2): 194-197.

DiekJoвsт H. 1994. Der nepalesische Knöterich (Polygonum nepalense Meisn.), ein Neufund in Deutschland. Floristische Rundbriefe 27(2): 90-93.

Dzwonko Z. 2007. Przewodnik do badań fitosocjologicznych. Instytut Botaniki Uniwersytetu Jagiellońskiego \& Sorus, Kraków - Poznań.

Galasso G., Banfi E., De Mattia F., Grassi F., Sgorbati S. \& Labra M. 2009. Molecular phylogeny of Polygonum L. s.l. (Polygonoideae, Polygonaceae), focusing on European taxa: preliminary results and systematic considerations based on $r b c \mathrm{~L}$ plastidial sequence data. Atti Soc. Ital. Sci. Nat. Mus. Civico Storia Nat. 150(1): 113-148.

Gebre H., Tarekegne A. \& Asmare E. 1988. Preliminary indications on the importance of yield limiting factors on wheat. In: M. VAN Ginkel \& D. TANnER (eds), The Fifth Regional Wheat Workshop for Eastern, Central and Southern Africa and the Indian Ocean, pp. 189-193. CIMMYT, Mexico.

Hinds H. R. \& Freeman C. C. 2005. Persicaria. In: Flora of North America Editorial Committee (eds), Flora of North America North of Mexico. 5: 574-594. Oxford University Press, New York and Oxford.

JørGENSEN P. M. \& LEón-Yánez S. (eds) 1999. Catalogue of the vascular plants of Ecuador. Monogr. Syst. Bot. Missouri Bot. Gard. 75: 1-1181.

Kefyalew G., Shambel M., Amanuel G., Workiye T. \& MeKONNEN K. 2000. Survey of weed community structure in bread wheat in three districts of Arsi Zone in south-eastern Ethiopia. In: CIMMYT, The Eleventh Regional Wheat Workshop for Eastern, Central and Southern Africa, pp. 291-301. CIMMYT, Addis Ababa.

KIM S.-T. \& Donoghue M. J. 2008. Molecular phylogeny of Persicaria (Persicarieae, Polygonaceae). Syst. Bot. 33(1): 77-86. 
KubÁt K. \& JehlíK V. 2003. Persicaria pensylvanica in der Tschechischen Republik. Preslia 75: 183-188.

Lambdon P. W., Pyšek P., Bosnou C., Hejda M., Arianoutsou M., Essl F. Jarošík V., Pergl J., Winter M., Anastasiu P., Andriopoulos P., Bazos I., Brundu G., Celesti-Grapow L., Chassot P. \& Vilŕ M. 2008. Alien flora of Europe: species diversity, temporal trends, geographical patterns and research needs. Preslia 80: 101-149.

Li A., Bao B., Grabovskaya-Borodina A. E., Honh S., McNeill J., Moskayin S. L., Ohba H. \& Park C.-W. 2003. Polygonaceae. In: Z. Y. Wu, P. H. Raven \& D. Y. Hong (eds), Flora of China. 5: 277-350, Science Press, Beijing \& Missouri Botanical Garden Press, St. Louis.

Li X., Li R., Chu S., Zhang Y., Wang Y. \& Xu R. 2012. Species and distribution of weeds in tobacco fields in Shiyan, Hubei Province. Chinese Tobacco Science 33(4): 55-59.

MeIER W. 2006. Contribución al conocimiento de Persicaria nepalensis (Meisn.) H. Gross y P. capitata (Buch.-Ham. ex D. Don) H. Gross, especies invasoras en el Parque Nacional el Ávila, Venezuela. Acta Bot. Venez. 29(1): 1-16.

Mirek Z., Piękoś-Mirkowa H., Zając A., ZająC M. (eds) 2002. Flowering plants and pteridophytes of Poland a checklist. W. Szafer Institute of Botany, Polish Academy of Sciences, Kraków.

NimJE P. M. 1988. Weed survey of potato fields of the higher hills of Nilgiris. Indian Journal of Weed Science 20(4): 26-31.

Nuoroge J. M. 1994. Weeds and weed control in coffee. Exp. Agric. 30(4): 421-430.

Nogueira I., Ortiz S. \& Paiva J. A. R. 2006. Polygonaceae. In: G. V Pope, R. M. Polhill \& E. S. Martins (eds), Flora Zambesiaca. 9(3): 1-49. Royal Botanic Gardens, Kew.

Pignatti-Wikus E. 1973. Polygonum nepalense Meisn. avventizia nel Bellunese. Giorn. Bot. Ital. 107(6): 291-294.
QAiser M. 2001. Polygonaceae. In: S. I. Ali \& M. QAISER (eds), Flora of Pakistan. 205: 1-205. University of Karachi, Karachi \& Missouri Botanical Garden Press, St. Louis.

Roder W., Dochen T., Nidup K. \& DorJi S. 2009. Weed management challenges in small-holder potato systems in Bhutan. Weed Research 49(3): 300-307.

Stace C. 2010. New flora of the British Isles. $3^{\text {rd }}$ ed. Cambridge University Press, Cambridge.

TAN K. \& Baytop A. 1995. Polygonum nepalense Meisn. in Turkey. Turkish J. Bot. 19(6): 601-602.

ToKARSKA-GuZIK B., DAJdoK Z., ZAJĄC M., ZAJĄC A., URBISZ A., DANielewicz W. \& HoldyŃSKi C. 2012. Alien plants in Poland with particular reference to invasive species. Generalna Dyrekcja Ochrony Środowiska, Warszawa (in Polish with English summary).

Verloove F. 2013. Persicaria nepalensis. In: Manual of the Alien Plants of Belgium. [August 2013]. http://alienplantsbelgium.be/node/3689.

Vibrans H. \& Hanan-Alipi A. M. 2008. Polygonum nepalense (Polygonaceae), una planta invasora nueva para México. Acta Bot. Mex. 82: 1-6.

Webb D. A., Chater A. O. \& Akeroyd J. R. 1993. Polygonum L. In: T. G. Tutin, N. A. Burges, A. O. Chater, J. R. Edmondson, V. H. Heywood \& D. M. Moore (eds), Flora Europaea. 1: 91-97. Cambridge University Press, Cambridge.

Yasmin G. 2009. Taxonomic studies of two major genera Polygonum L. (complex) and Rumex L. of Polygonaceae from Pakistan. PhD thesis. Department of Plant Sciences Quaid-i-Azam University, Islamabad.

Received 27 December 2013 